\title{
Erratum to: Antarctica challenges the new horizons in predictive, preventive, personalized medicine: preliminary results and attractive hypotheses for multi- disciplinary prospective studies in the Ukrainian "Akademik Vernadsky" station
}

\author{
Yevhen V. Moiseyenko ${ }^{1,2}$, Viktor I. Sukhorukov ${ }^{3}$, Georgiy Yu Pyshnov ${ }^{4}$, Iryna M. Mankovska², Kateryna V. Rozova ${ }^{2}$,

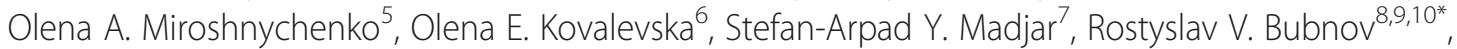 \\ Anatoliy O. Gorbach ${ }^{8,10}$, Kostiantyn M. Danylenko ${ }^{1}$ and Olga I. Moiseyenko ${ }^{11}$
}

\section{Erratum}

After publication of the original article [1] it was brought to our attention that incorrect data was given in the second paragraph of the 'Methods' section.

The original text reads as:

In addition, their duration in the Antarctic is much more powerful and higher than that registered in Ukraine. Subzero temperatures in the winter rarely exceed $300{ }^{\circ} \mathrm{C}$ and in summer during a very short period (only during the day) can rise over $0{ }^{\circ} \mathrm{C}$. The average annual temperature in the region of the station is $40{ }^{\circ} \mathrm{C}$, compared to $+90{ }^{\circ} \mathrm{C}$ in Ukraine.

However, the corrected version should now read as follows:

In addition, their duration in the Antarctic is much more powerful and higher than that registered in Ukraine. Subzero temperatures in the winter rarely exceed $-30{ }^{\circ} \mathrm{C}$ and in summer during a very short period (only during the day) can rise over $0{ }^{\circ} \mathrm{C}$. The average annual temperature in the region of the station is $-4{ }^{\circ} \mathrm{C}$, compared to $+9{ }^{\circ} \mathrm{C}$ in Ukraine.

This has been corrected on the BMC website.

\begin{abstract}
Author details
${ }^{1}$ National Antarctic Scientific Center of Ministry of Education of Ukraine, 16, Taras Shevchenko Boulevard, Kyiv 01601, Ukraine. ${ }^{2}$ Bogomoletz Institute of Physiology, National Academy of Sciences of Ukraine, 4, Bogomoletz str., Kyiv 01024, Ukraine. Institute of Neurology, Psychiatry and Narcology of the National Academy of Medical Sciences of Ukraine, 46, Akademika Pavlova str., Kharkiv 61068, Ukraine. ${ }^{4}$ Institute for Occupational Health of National Academy of Medical Sciences of Ukraine, Saksaganskogo str. 75, Kyiv 01033, Ukraine. ${ }^{5}$ Zhytomyr Ivan Franko State University, 40, Velyka Berdychivska Str., Zhytomyr 10008, Ukraine. ${ }^{6}$ G.S. Kostyuk Institute of Psychology of the National Academy of Pedagogical Sciences of Ukraine, 2, Pankivska str., Kyiv 01033, Ukraine. 'Budapest University of Technology and Economics, Budapest, Hungary. ${ }^{8} \mathrm{Clinical}$ Hospital 'Pheophania' of State Management of Affairs Department, 21, Zabolotny str., Kyiv 03680, Ukraine.

${ }^{9}$ Zabolotnylnstitute of Microbiology and Virology, National Academy of Sciences of Ukraine, 154, Zabolotny Str., Kyiv 03680, Ukraine. ${ }^{10}$ Ukrainian Academy of Informatics, Kyiv, Ukraine. " National Scientific Center 'Mykola Strazhesko Institute of Cardiology' of National Academy of Medical Sciences of Ukraine, 5, Narodnoho Opolchennya str., Kyiv, Ukraine.
\end{abstract}

Received: 6 July 2016 Accepted: 6 July 2016

Published online: 18 July 2016

\section{References}

1. Moiseyenko et al. Antarctica challenges the new horizons in predictive, preventive, personalized medicine: preliminary results and attractive hypotheses for multi-disciplinary prospective studies in the Ukrainian "Akademik Vernadsky" station. The EPMA Journal. 2016;7:11.

* Correspondence: rostbubnov@gmail.com

${ }^{8}$ Clinical Hospital 'Pheophania' of State Management of Affairs Department,

21, Zabolotny str., Kyiv 03680, Ukraine

${ }^{9}$ Zabolotnylnstitute of Microbiology and Virology, National Academy of

Sciences of Ukraine, 154, Zabolotny Str., Kyiv 03680, Ukraine 